2019-06-20

\title{
Enhanced sulfide removal and
}

bioelectricity generation in microbial fuel

cells with anodes modified by vertically

oriented nanosheets

\author{
Yang, M
}

http://hdl.handle.net/10026.1/17680

10.1080/09593330.2018.1429496

Environmental Technology

Informa UK Limited

All content in PEARL is protected by copyright law. Author manuscripts are made available in accordance with publisher policies. Please cite only the published version using the details provided on the item record or document. In the absence of an open licence (e.g. Creative Commons), permissions for further reuse of content should be sought from the publisher or author. 

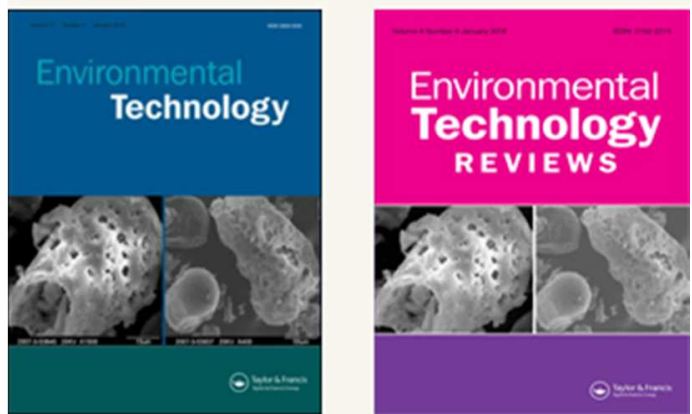

\section{Enhanced sulfide removal and bioelectricity generation in microbial fuel cells with anodes modified by vertically oriented nanosheets}

\begin{tabular}{|r|l|}
\hline Journal: & Environmental Technology \\
\hline Manuscript ID & TENT-TENT-2017-1395.R2 \\
\hline Date Submitted by the Author: & n/a \\
\hline Complete List of Authors: & $\begin{array}{l}\text { Yang, Meng; China Unversity of Geoscience Beijing } \\
\text { Zhong, Yuezhi; China Unversity of Geoscience Beijing } \\
\text { Zhang, Baogang; China Unversity of Geoscience Beijing, } \\
\text { Shi, Jiaxin; China Unversity of Geoscience Beijing } \\
\text { Huang, Xueyang; China Unversity of Geoscience Beijing } \\
\text { Xing, Yi; University of Science and Technology Beijing } \\
\text { Su, Lin; Southeast University } \\
\text { Liu, Huipeng; China Unversity of Geoscience Beijing } \\
\text { Borthwick, Alistair G.L.; University of Edinburgh School of GeoSciences }\end{array}$ \\
\hline Keywords: & $\begin{array}{l}\text { Sulfide, Nano-sheets, Microbial fuel cells, Microbial community, Carbon- } \\
\text { fiber-felt }\end{array}$ \\
\hline &
\end{tabular}

\section{SCHOLARONE}

Manuscripts 


\section{Enhanced sulfide removal and bioelectricity generation in microbial}

2 fuel cells with anodes modified by vertically oriented nanosheets

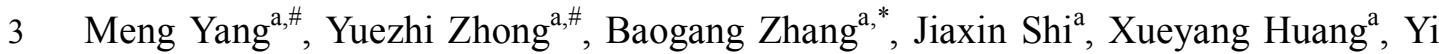

$4 \quad$ Xing $^{\text {b,* }}$, Lin $\mathrm{Su}^{\mathrm{c}}$, Huipeng Liu ${ }^{\mathrm{a}}$, Alistair G.L. Borthwick ${ }^{\mathrm{d}}$

$5 \quad{ }^{a}$ School of Water Resources and Environment, MOE Key Laboratory of Groundwater

6 Circulation and Environmental Evolution, China University of Geosciences (Beijing),

$7 \quad$ Beijing 100083, P. R. China

$8{ }^{b}$ School of Energy and Environmental Engineering, University of Sciences and

9 Technology Beijing, Beijing Key Laboratory of Resource-oriented Treatment of

10 Industrial Pollutants, Beijing 100083, P. R. China

$11{ }^{c}$ State Key Laboratory of Bioelectronics, Southeast University, Nanjing 210096, P. R.

12 China

$13{ }^{d}$ School of Engineering, The University of Edinburgh, The King's Buildings,

14 Edinburgh EH9 3JL, UK

15

\section{Abstract}

Anode materials and structures are of critical importance for microbial fuel cells (MFCs) recovering energy from toxic substrates. Carbon-fiber-felt anodes modified by layers of vertically oriented $\mathrm{TiO}_{2}$ and $\mathrm{Fe}_{2} \mathrm{O}_{3}$ nanosheets respectively were applied in present study. Enhanced sulfide removal efficiencies (both over 90\%) were obtained after $48 \mathrm{~h}$ operation, with maximum power densities improved by 1.53 and 1.36 folds compared with MFCs with raw carbon-fiber-felt anode, respectively. The

\footnotetext{
\# These authors contributed equally to this work.

* Corresponding author. Tel.: +86108232 2281; fax: +861082321081.

E-mail: zbgcugb@gmail.com, baogangzhang@cugb.edu.cn (B. Zhang); xing_bkd@163.com (Y.Xing).
} 
modified anodes provided more active sites for microbial adhesion with increasing biomass densities. High-throughput 16S rRNA gene sequencing analysis also indicated the increase of microbial diversities. Bacteroidetes responsible for bioelectricity generation with Thiobacillus and Spirochaeta dominating sulfide removal were found in the MFCs with the modified anodes, with less anaerobic fermentative bacteria as Firmicutes appeared. This indicates that the proposed materials are competitive for applications of MFCs generating bioelectricity from toxic sulfide.

Keywords: Sulfide; Nano-sheets; Microbial fuel cells; Microbial community; Carbon-fiber-felt

\section{Introduction}

Sulfide is a hazardous, corrosive and odorous substance that often occurs in industrial wastewaters, especially in effluent from viscose rayon industries, petrochemical plants and tanneries $[1,2]$. Sulfide is toxic to human health, with studies showing that sulfide is particularly harmful to cytochrome c oxidase and causes cell hypoxia [3]. Thus, sulfide-contaminated wastewater must be treated thoroughly before discharge into the environment. Although common physical-chemical methods, such as adsorption and chemical oxidation, can remove sulfide, they are costly to implement and require high energy inputs [4]. In contrast, biological processes provide an environmental-friendly alternative for sulfide removal from both liquids and gases under ambient environmental conditions [5-7]. 
65

66

67

68

69

$$
\begin{aligned}
& \mathrm{HS}^{-} \rightarrow \mathrm{S}^{0}+\mathrm{H}^{+}+2 \mathrm{e}^{-} \\
& \mathrm{S}^{0}+4 \mathrm{H}_{2} \mathrm{O} \rightarrow \mathrm{SO}_{4}{ }^{2-}+8 \mathrm{H}^{+}+6 \mathrm{e}^{-}
\end{aligned}
$$

Commonly, co-substrate such as glucose is supplied as co-existing electron donor [4], which is oxidized as Equ. (3),

$$
\mathrm{C}_{6} \mathrm{H}_{12} \mathrm{O}_{6}+6 \mathrm{H}_{2} \mathrm{O} \rightarrow 6 \mathrm{CO}_{2}+24 \mathrm{H}^{+}+24 \mathrm{e}^{-}
$$

$$
\text { Moreover, other contaminants with higher redox potentials such as nitrate may be }
$$
presented with sulfide [22]. It can also act as competitive electron acceptor, which is reduced as Equ. (4),

$$
2 \mathrm{NO}_{3}^{-}+12 \mathrm{H}^{+}+10 \mathrm{e}^{-} \rightarrow \mathrm{N}_{2}+6 \mathrm{H}_{2} \mathrm{O}
$$

Then electrons flow to cathode via external circuits. In cathode chambers, oxygen and potassium ferricyanide are most frequently used as electron acceptors and they are reduced as Equ. (5) and (6) [23,24],

$$
\begin{aligned}
& \mathrm{O}_{2}+4 \mathrm{H}^{+}+4 \mathrm{e}^{-} \rightarrow 2 \mathrm{H}_{2} \mathrm{O} \\
& \mathrm{Fe}(\mathrm{CN})_{6}{ }^{3-}+\mathrm{e}^{-} \rightarrow \mathrm{Fe}(\mathrm{CN})_{6}^{4-}
\end{aligned}
$$

While most of these studies focus on co-existing pollutants removals [4,22,24-26], operating factors investigations [27] and commercial electrodes comparisons [28].

Little attention has been paid to date on modified carbon-based anode especially for carbon fiber felt to enhance bioelectricity generation and sulfide removal in the context of accumulation of microbes in anode chambers with toxic matrix. The present research explores carbon-fiber-felt anodes modified with two kinds of metal oxides $\left(\mathrm{TiO}_{2}\right.$ and $\left.\mathrm{Fe}_{2} \mathrm{O}_{3}\right)$ nanosheets respectively that are vertically oriented on the surface. Enhanced performances in aspects of power outputs and sulfide removals 
are investigated for MFCs equipped with these anodes, compared with unmodified one. The amounts and species of accumulated microbes are also analyzed. This work technology with proposed anodes.

\section{Materials and methods}

\subsection{Preparation of anodes and fabrication of MFCs}

$\mathrm{TiO}_{2}$ and $\mathrm{Fe}_{2} \mathrm{O}_{3}$ sols were synthesized in the laboratory following a previous report [17,18]. Clean carbon-fiber-felt materials ( $3 \mathrm{~mm}$ thickness, $4 \mathrm{~cm}$ length and width, provided by Beijing Evergrow Resources CO., LTD, China) were immersed in the $\mathrm{TiO}_{2}$ and $\mathrm{Fe}_{2} \mathrm{O}_{3}$ sols for 10 min and dried at $80{ }^{\circ} \mathrm{C}$. After that, the materials were calcined for $30 \mathrm{~min}$ in a tubular furnace at $350{ }^{\circ} \mathrm{C}$ so that a $\mathrm{TiO}_{2}$ and $\mathrm{Fe}_{2} \mathrm{O}_{3}$ seed layers formed on the surfaces of the carbon-fiber felts. A Teflon-lined stainless steel autoclave $(50 \mathrm{~mL}$ in volume) filled with $40 \mathrm{~mL}$ of aqueous solution of $10 \mathrm{M} \mathrm{NaOH}$ and $0.2 \mathrm{~g}$ of $\mathrm{AC}$ powder was placed in an oven at $180^{\circ} \mathrm{C}$ for $24 \mathrm{~h}$. After the carbon-fiber-felts had cooled down to room temperature, the modified carbon-fiber felts were rinsed with ultrapure water to remove $\mathrm{AC}$, followed by soaking with $0.1 \mathrm{M}$ hydrochloric acid for $1 \mathrm{~h}$, then washed to neutral with deionized water and dried at $80{ }^{\circ} \mathrm{C}$. Sequentially, the samples were calcined at $550{ }^{\circ} \mathrm{C}$ for $1 \mathrm{~h}$ in a $\mathrm{N}_{2}$ atmosphere $[17,18]$. 
108

109

110

111

112

113

114

115

116

117

118

119

120

121

122

123

124

125

126

127

128

proton exchange membrane (Nafion117\#. Dupont, USA) with a surface area about 4 $\mathrm{cm}^{2}$. The MFCs were equipped with $\mathrm{TiO}_{2}$ nanosheets modified carbon-fiber-felt anode $\left(\mathrm{MFC}-\mathrm{TiO}_{2}\right)$ and $\mathrm{Fe}_{2} \mathrm{O}_{3}$ nanosheets modified carbon-fiber-felt anode $\left(\mathrm{MFC}-\mathrm{Fe}_{2} \mathrm{O}_{3}\right)$, respectively, as prepared above, with surface area of $16 \mathrm{~cm}^{2}$. Raw carbon-fiber-felt anode without modification was also employed as control (MFC-CF). All cathodes were made of ordinary carbon-fiber-felt with the same size as anodes. The anode and cathode were connected across a $100 \Omega$ external resistor. Each anode chamber was inoculated with $25 \mathrm{~mL}$ anaerobic granular sludge from an up-flow anaerobic sludge blanket (UASB) reactor treating high strength sulfate wastewater. The anolyte included the following (per L): $0.75 \mathrm{~g}$ of $\mathrm{C}_{6} \mathrm{H}_{12} \mathrm{O}_{6} ; 5.62 \mathrm{~g}$ of $\mathrm{NaH}_{2} \mathrm{PO}_{4} \cdot 2 \mathrm{H}_{2} \mathrm{O} ; 6.15 \mathrm{~g}$ of $\mathrm{Na}_{2} \mathrm{HPO}_{4} \cdot 12 \mathrm{H}_{2} \mathrm{O} ; 0.31 \mathrm{~g}$ of $\mathrm{NH}_{4} \mathrm{Cl} ; 0.13 \mathrm{~g}$ of $\mathrm{KCl} ; 1.25 \mathrm{~mL}$ of vitamin solution; and $12.5 \mathrm{~mL}$ of trace mineral element solution. Sulfide was added to the anode solution in the form of $\mathrm{Na}_{2} \mathrm{~S} \cdot 9 \mathrm{H}_{2} \mathrm{O}$ with concentration of $60 \mathrm{mg} \mathrm{L}^{-1}$ to facilitate the comparison [30]. The catholyte included the following (Per L): $9 \mathrm{~g}$ of $\mathrm{KH}_{2} \mathrm{PO}_{4}, 8 \mathrm{~g}$ of $\mathrm{K}_{2} \mathrm{HPO}_{4} \cdot 3 \mathrm{H}_{2} \mathrm{O}$ and $0.05 \mathrm{~g} \mathrm{~K}_{3}\left[\mathrm{Fe}(\mathrm{CN})_{6}\right]$.

\subsection{Experimental procedures}

\section{Morphology and composition of the modified anodes were analyzed first. Then} successful start-up of all MFCs was realized by refreshing anolyte every 2 days. After that, the power outputs and sulfide removals in a typical cycle (48 h) were evaluated, noting that most of the sulfide was removed within that time. Electrochemical measurements were also undertaken for the three types of MFC. After 3 months 
129

130

132

operation with refreshment of anolyte every 2 days, ultrasonic was employed to collect the bacteria attached to the surfaces of the anodes, and the samples then used for high-throughput 16S rRNA gene sequencing on MiSeq (Illumina, the USA). All experiments were carried out at room temperature $\left(22 \pm 2{ }^{\circ} \mathrm{C}\right)$ for practical application consideration and easy comparison with existing studies [22]. For each condition, trials were carried out in triplicate and average results from the three MFCs were reported.

\subsection{Analytical methods and data representation}

Measurement of chemical oxygen demand (COD) was undertaken based on digestion with potassium dichromate in concentrated sulfuric acid for $2 \mathrm{~h}$ at $150{ }^{\circ} \mathrm{C}$.

Sulfide was determined according to the methylene blue method $(\mathrm{n}=665 \mathrm{~nm})$ [31].

The indication of "sulfide" described all species $\left(\mathrm{H}_{2} \mathrm{~S}, \mathrm{HS}^{-}\right.$, and $\left.\mathrm{S}^{2-}\right)$. Total organic carbon (TOC) was monitored by Multi N/C 3000 TOC analyzer (Analytik Jena AG,

Germany). Sulfate was measured by ion chromatography (ICS-1600, Dionex, the USA). pH was measured using a pH-201 meter (Hanna, Italy). The biomass on the anode surface was determined using the phospholipid analysis as previously described and the biomass density was expressed as the mass of phosphorus normalized by anode volume $\left(48 \mathrm{~cm}^{3}\right)$ [32]. The morphology and composition of modified anodes were analyzed by a JEOL JAX-840 scanning electron microscope (SEM) operating at $20 \mathrm{kV}$ with an energy dispersive X-ray (EDX).

Voltage measurements were taken using a voltmeter throughout the test. The 
150 polarization curve and power outputs were obtained by varying the external resistance

151 over the range from 10 to $5000 \Omega$. For each point on the polarization curve, readings

152 were taken when pseudo-steady-state conditions was established, which might take

153 several minutes or more [4,33,34]. MFCs operated at least twice under each resistance

154 to ensure the repeatability of power outputs. Power density was normalized to the

155 single-side projected surface area of the anode. Cyclic voltammetry (CV)

156 measurement was carried out at a scan rate of $2 \mathrm{mV} \mathrm{s}^{-1}$ in the range of $-1 \mathrm{~V}$ to $+1 \mathrm{~V}$

157 using an electrochemical workstation (VMP3, Bio-Logic Science Instruments, France)

158 with $\mathrm{Ag} / \mathrm{AgCl}$ as reference electrode. Electrochemical impedance spectroscopy (EIS)

159 measurement was conducted over a frequency range of $100 \mathrm{kHz}$ to $1 \mathrm{mHz}$ with an $\mathrm{AC}$

160 signal of $10 \mathrm{mV}$ amplitude. All electrolyte solutions were deaerated by high-purity

161 nitrogen for at least 15 minutes prior to the measurement [32]. Coulombic efficiency

162 (CE) was calculated as reported previously [4].

163 Molecular biology analysis was performed to obtain the characteristics of the

164 microbial population. Total genomic DNA was collected, pooled, and amplified

165 according to previous procedures [35]. Then a mixture of amplicons was used for

166 high-throughput 16S rRNA gene sequencing on MiSeq (Illumina, the USA). Raw

167 sequencing data were deposited in the NCBI Sequence Read Archive with access

168 number of SPR067096 and were analyzed according to Hao et al. [35]. 
169

170

171

172

174

175

176

177

178

179

180

181

182

183

184

185

186

187

188

\section{Results and discussion}

\subsection{Characteristics of the modified anodes}

It was observed that the modified carbon-fiber-felt surfaces were covered with dense layers, comprising vertically oriented nanosheets on top, which formed vertical pores through the layer, compared with raw carbon-fiber-felt anode (Fig. 1a, Fig. 1b, Fig. 1c). This structure improved the roughness of the anode surface, which was similar with previous studies $[17,18]$ and meant that the $3 \mathrm{D}$ open porous structure was favorable to biofilm growth as well as permeability of electrolyte, substrates, and electron mediators [36]. These vertically oriented nanosheets extending upward from the surface of carbon-fiber-felts could provide direct pathways for electrons to transfer from exoelectrogens in the biofilm to the carbon-fiber-felts. Moreover, carbon-fiber-felts with larger specific surface areas were selected as the basic material in present study instead of plain carbon paper, which would provide more sites for microbes' attachment $[17,18]$. The compositions of the modified anodes were examined using EDX and the corresponding elements (Ti, Fe, O) were detected (Fig. 1d), indicating that the anodes were well modified with metal oxides. It was interesting to note that some metal oxides could not only enhance the interfacial electron transfers in MFCs [17] but also stimulate the growth of chemoautotrophic and heterotrophic bacteria using solar energy [37]. This implied that the proposed modified anodes were promising and ready for following experiments. 
189

190

191

192

193

194

195

196

197

198

199

200

201

202

203

204

205

206

207

208

209

210

\subsection{Bioelectricity generation by the MFCs}

Polarization curves were obtained using closed-circuit MFCs during $48 \mathrm{~h}$ operation

(Fig. 2a). MFC-TiO 2 exhibited the highest maximum power density of $607.8 \pm 16.1$

$\mathrm{mW} \mathrm{m}{ }^{-2}$ at current density of $1591.38 \mathrm{~mA} \mathrm{~m}^{-2}$ with $150 \Omega$ external resistances,

followed by MFC-Fe $\mathrm{O}_{3}$ with this value of $537.6 \pm 14.8 \mathrm{~mW} \mathrm{~m}^{-2}$ at current density of

$1296.15 \mathrm{~mA} \mathrm{~m}^{-2}$ with $200 \Omega$ external resistances, 1.53 and 1.36 folds higher than the

maximum power output of MFC-CF $\left(396.1 \pm 11.7 \mathrm{~mW} \mathrm{~m}^{-2}\right.$ with $400 \Omega$ external

resistances), while the maximum power output of MFC-CF was slightly higher than

that obtained from previous study, where maximum power output of $283 \mathrm{~mW} \mathrm{~m}^{-2}$ was

obtained in dual chamber MFCs (300 mL net volume for anode chamber) with 300

$\mathrm{mg} \mathrm{L}^{-1}$ initial sulfide concentration [25]. The results indicated that the modified

anodes with the $\mathrm{TiO}_{2}$ and $\mathrm{Fe}_{2} \mathrm{O}_{3}$ nanosheets vertically oriented on the surface of

carbon-fiber-felt could increase the power output of MFCs by providing more sites for

microbes' attachment and more direct electrons transfer pathways [17,18].

Anode potentials which dominated the above difference were also monitored

during this period (Fig. 2b). The anode potentials of the MFC-CF were lower than

those obtained with sulfide free substrate due to lower redox potential of sulfide

$[38,39]$. Additionally, the sulfide added to the anodic solution and the sulfate produced

through sulfide oxidation acted as a soluble redox mediator, which could promote

electron transfer from the bacterial cells to the anode surface [40]. The anode

potentials of both $\mathrm{MFC}-\mathrm{TiO}_{2}$ and $\mathrm{MFC}-\mathrm{Fe}_{2} \mathrm{O}_{3}$ were further lower than those of

MFC-CF. It should be noted that previous results had shown that the lower negative 
anode potential could demonstrate better activity of anode communities [41].

Moreover, metal oxides possess superior electronic, optical, and dielectric properties and had been employed for surface modifications of anodes in MFCs for high power output [36]. Hence, the present results indicated that carbon-fiber-felt with $\mathrm{TiO}_{2}$ and

\title{
3.3 Sulfide and organics removals in the MFCs
}

\author{
Concentrations of sulfide and generated sulfate as well as TOC were monitored \\ initially and after $48 \mathrm{~h}$ operation (Fig. 4). Both sulfide and TOC declined after the \\ operation, demonstrating the feasibility of MFC technology for the removal of sulfide
}


233 and organic carbon simultaneously. Similar as the power outputs, sulfide removal

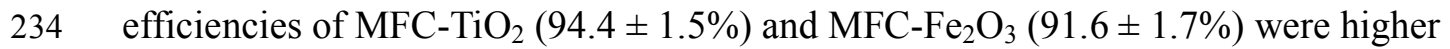

235 than that of MFC-CF $(88.5 \pm 1.9 \%)$, with the removal efficiency obtained from

236 MFC-CF comparable with results from dual chamber MFCs that $84.7 \%$ of $100 \mathrm{mg} \mathrm{L}^{-1}$

237 sulfide in the influent was removed within $72 \mathrm{~h} \mathrm{[4]} \mathrm{and} \mathrm{higher} \mathrm{than} \mathrm{removal} \mathrm{efficiency}$

238 of $60 \%$ with $80 \mathrm{mg} \mathrm{L}^{-1}$ initial sulfide concentration in $72 \mathrm{~h}$ operation [26].

239 Nevertheless, sulfide removal efficiencies obtained in this study were relatively lower

240 than those achieved by Cai et al. [43], where above $99 \%$ of added sulfide were

241 removed, as our used cathode electron acceptor $\left(\mathrm{K}_{3}\left[\mathrm{Fe}(\mathrm{CN})_{6}\right]\right)$ possesses lower redox

242 potential than their employed $\mathrm{KMnO}_{4}$ [24]. The TOC removal efficiencies also

243 exhibited the similar principles, with $\mathrm{MFC}-\mathrm{TiO}_{2}(56.9 \pm 1.8 \%)$ and $\mathrm{MFC}-\mathrm{Fe}_{2} \mathrm{O}_{3}(55.2$

$244 \pm 1.4 \%)$ higher than that of MFC-CF $(31.7 \pm 1.7 \%)$. The removal efficiencies of

245 sulfide were superior to the TOC indicated that sulfide and organics acted as

246 co-electron donors with competitive relationship and sulfide was easier to be oxidized

247 than organic matter because of its lower redox potential [44,45]. Moreover, the

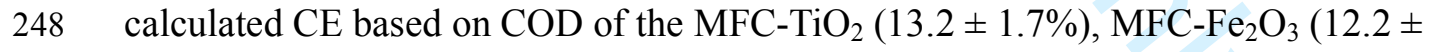

$2491.6 \%)$ and MFC-CF $(11.4 \pm 1.8 \%)$ was comparable with similar systems as previously

250 reported [4]. This implied that carbon-fiber-felt with these two kinds of metal oxide

$251\left(\mathrm{TiO}_{2}\right.$ and $\left.\mathrm{Fe}_{2} \mathrm{O}_{3}\right)$ nanosheets vertically oriented on its surface as promising anode

252 material could enhance both sulfide and organics removals in MFCs.

253 Oxidation products of sulfide in the MFCs were investigated. After $48 \mathrm{~h}$

254 operation, concentrations of generated sulfate in the exhausted anolyte were $3.26 \pm$ 
255

256

257

258

259

260

261

262

263

264

265

266

267

268

269

270

271

272

273

274

275

276

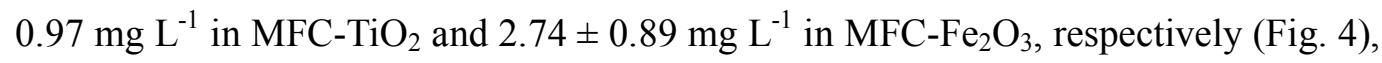
with other soluble species $\left(\mathrm{S}_{2} \mathrm{O}_{3}{ }^{-}, \mathrm{SO}_{3}{ }^{2-}\right)$ undetected in all MFCs, suggesting that most oxidation products were insoluble. In fact, many obvious solid particles covered on the anode surfaces after operation (Figure S1, Supporting Information). The particles were examined using EDX and it was found that the main component was elemental sulfur (Fig. 1d), which was the expected oxidation product as it was a non-corrosive solid and was easy to remove from aqueous solutions [4]. The present results suggested that elemental sulfur was the main product for sulfide removal when the electrochemical and biological oxidations were performed in MFCs, also proved by previous studies $[4,46]$. Recovery and quantification of generated elemental sulfurs were difficult as they mixed with biofilms. The relatively lower sulfate concentration and higher peak of elemental sulfur indicated that the modified carbon-fiber-felt electrodes were more amenable to biofilm growth, enabling more sulfur to be generated.

\subsection{Identification of the involved microbes}

The monitored voltage outputs and sulfide removals were relatively stable during the whole experiment. After 3 months operation, it was found that the biomass densities of the MFC-TiO $2\left(26.7 \mu \mathrm{g} \mathrm{cm}^{-1}\right)$ and MFC-Fe ${ }_{2} \mathrm{O}_{3}\left(22.1 \mu \mathrm{g} \mathrm{cm}^{-1}\right)$ were higher than that of MFC-CF $\left(16.2 \mu \mathrm{g} \mathrm{cm}^{-1}\right)$, suggesting more microbes adhering on the modified anodes (Figure S1, Supporting Information). Total numbers of operational taxonomy units (OTUs) estimated by Chao and Ace estimators with infinite sampling in $\mathrm{MFC}-\mathrm{TiO}_{2}$ and $\mathrm{MFC}-\mathrm{Fe}_{2} \mathrm{O}_{3}$ were much larger than that in MFC-CF (Table 1), 
277 indicating that $\mathrm{MFC}-\mathrm{TiO}_{2}$ and $\mathrm{MFC}-\mathrm{Fe}_{2} \mathrm{O}_{3}$ possessed greater richness of microbial

278 diversity than MFC-CF. Both Simpson and Shannon diversity index provide not only

279 the simply species richness (i.e., the number of species present) but how the

280 abundance of each species is distributed (the evenness of the species) among all the

281 species in the community. The increase of Shannon index and decrease of Simpson

282 index of MFCs with modified anodes compared with raw one implied the bacterial

283 communities in $\mathrm{MFC}-\mathrm{TiO}_{2}$ and $\mathrm{MFC}-\mathrm{Fe}_{2} \mathrm{O}_{3}$ were more diverse than those in the

284 MFC-CF due to the stimulated growth bacteria with the added metal oxides [36].

285 Besides, visible light-excited photoelectrons from metal oxide could stimulate the

286 growth of chemoautotrophic and heterotrophic bacteria [37].

287 16S rRNA gene sequence and taxonomy analyses for the microbes in the three

288 MFCs were performed at phylum, class and genus levels in order to understand the

289 role of bacteria in enhanced sulfide oxidation and bioelectricity generation (Table 2).

290 Electrochemically activated bacteria that were conducive to bioelectricity generation

291 were enriched in the MFCs, especially with modified anodes. Bacteroidetes, the most

292 frequently appeared species in the anode biofilms of MFCs with electrochemical

293 activity as reported by $\mathrm{Ha}$ et al. [46] were enriched in $\mathrm{MFC}^{-\mathrm{TiO}_{2}}(4.94 \%)$ and

294 MFC-Fe ${ }_{2} \mathrm{O}_{3}(1.45 \%)$ than those in MFC-CF (1.22\%). Moreover, with the

295 enhancement of MFCs' functions of electricity generation and sulfide removal, plenty

296 of bacteria with electrochemical activity were domesticated, such as the

297 Deltaproteobacteria species, especially in the MFCs with modified anode. This

298 implied that the design with $\mathrm{TiO}_{2}$ and $\mathrm{Fe}_{2} \mathrm{O}_{3}$ nanosheets vertically oriented on the 
299

300

surface of carbon-fiber-felt could accumulate more electrochemically activated bacteria to generate bioelectricity than the untreated anode.

Sulfur related bacteria responsible for sulfide oxidation and sulfate reduction were also detected. Thiobacillus in Alphaproteobacteria, a famous sulfur-oxidizing bacterium that can oxidize sulfur to sulfate was enriched in $\mathrm{MFC}^{-\mathrm{TiO}_{2}}[43,47]$. Spirochaeta of Spirochaetes requiring sulfide in the growth medium and oxidizing it non-enzymically to elemental sulfur was found in $\mathrm{MFC}-\mathrm{Fe}_{2} \mathrm{O}_{3}$ [48]. Sulfate-reducing bacteria were also greatly enhanced in the MFCs with the proposed anodes, such as Desulfovibrio genus of Deltaproteobacteria, which could reduce sulfate as well as other sulfur species such as sulfite and thiosulfate [4,23]. These species worked together to realized higher sulfide removals in the improved MFCs.

Pseudoxanthomonas of Gammaproteobacteria with an abundance of $4.63 \%$ in MFC-CF could be responsible for sulfide removals in this reactor as this species can oxidize sulfide to sulfate [49]. More species of sulfur related bacteria were found in the three MFCs than previously reported by Sun et al. [50] who employed sulfide as the sole electron donor in the MFCs; the greater variety and numbers of bacteria probably occurred due to the complex substrate (glucose and sulfide) employed in the present study.

Less anaerobic fermentative bacteria without electrochemical activity appeared in the MFCs with modified anodes. Firmicutes accounted for the largest portion of bacteria found in anaerobic sludge [51] decreased more greatly in $\mathrm{MFC}^{-\mathrm{TiO}_{2}}$ and MFC-Fe ${ }_{2} \mathrm{O}_{3}$ than in MFC-CF. Rhodobacter sp. (belonging to Alphaproteobacteria) 
321 promoting anaerobic fermentation [52] also exhibited the similar principles. These

322 indicated that anaerobic fermentation process competing with bioelectricity

323 generation was further weakened when MFCs equipped with carbon-fiber-felt anodes

324 with $\mathrm{TiO}_{2}$ and $\mathrm{Fe}_{2} \mathrm{O}_{3}$ nanosheets vertically oriented on their surfaces.

325

326

327

328

329

330

331

332

333

334

335

336

337

338

339

340

\section{Conclusions}

The surfaces of carbon-fiber-felt were successfully modified by layers of vertically oriented $\mathrm{TiO}_{2}$ and $\mathrm{Fe}_{2} \mathrm{O}_{3}$ nanosheets respectively and acted as anodes in MFCs. Higher maximum power outputs of ${\mathrm{MFC}-\mathrm{TiO}_{2}}_{2}\left(607.75 \mathrm{~mW} \mathrm{~m}^{-2}\right)$ and MFC-Fe $\mathrm{O}_{3}\left(537.63 \mathrm{~mW} \mathrm{~m}{ }^{-2}\right)$ were obtained, compared with the MFC with untreated carbon-fiber-felt $\left(396.05 \mathrm{~mW} \mathrm{~m}^{-2}\right)$, and the sulfide and TOC removal efficiencies also increased. These results could be contributed to more active sites for microbial adhesion with increasing biomass densities by the modified anodes. Increases of microbial diversities were also observed by high-throughput 16S rRNA gene sequencing analysis and specific functional species were found, such as the enhanced Bacteroidetes responsible for bioelectricity generation with Thiobacillus and Spirochaeta dominating sulfide removal, with less anaerobic fermentative bacteria Firmicutes.

\section{Acknowledgements}

This research work was supported by the National Natural Science Foundation of China (NSFC) (No. 91647115). 


\section{References}

342

1. Celis-García LB, González-Blanco G, Meraz M. Removal of sulfur inorganic compounds by a biofilm of sulfate reducing and sulfide oxidizing bacteria in a down-flow fluidized bed reactor. J Chem Technol Biotechnol. 2008;83:260-268.

2. Long JW, Wallace JM, Peterson GW, Huynh K. Manganese oxide nanoarchitectures as broad-spectrum sorbents for toxic gases. ACS Appl Mater Interfaces. 2016;8:1184-1193.

3. Kim KH. The need for practical input data for modeling odor nuisance effects due to a municipal solid waste landfill in the surrounding environment. Environ Internat. 2016;87:116-117.

4. Zhang BG, Zhao HZ, Shi CH, Zhou SG, Ni JR. Simultaneous removal of sulfide and organics with vanadium (V) reduction in microbial fuel cells. J Chem Technol Biotechnol. 2009;84:1780-1786.

5. Henshaw PF, Zhu W. Biological conversion of hydrogen sulphide to elemental sulphur in a fixed-film continuous flow photo-reactor. Water Res. 2001;35:3605-3610.

6. Cirne DG, Van Der Zee FP, Fernandez-Polanco M, Fernandez-Polanco F. Control of sulphide during anaerobic treatment of S-containing wastewaters by adding limited amounts of oxygen or nitrate. Rev Environ Sci Biotechnol. 2008;7:93-105.

7. Lin HJ, Williams N, King A, Hu B. Electrochemical sulfide removal by low-cost electrode materials in anaerobic digestion. Chem Eng J. 2016; 297:180-192. 
363

364

365

366

367

368

369

370

371

372

373

374

375

376

377

378

379

380

381

382

383

384

8. Penteado ED, Fernandezmarchante CM, Zaiat M, Gonzalez ER, Rodrigo MA.

Influence of carbon electrode material on energy recovery from winery wastewater using a dual chamber microbial fuel cell. Environ Technol. 2017;38:1333-1341.

9. Du Q, An JK, Li JH, Zhou L, Li N, Wang X. Polydopamine as a new modification material to accelerate startup and promote anode performance in microbial fuel cells. J Power Sources. 2017;343:477-482.

10. Hao LT, Zhang BG, Tian CX, Liu Y, Shi CH, Cheng M, Feng CP. Enhanced microbial reduction of vanadium (V) in groundwater with bioelectricity from microbial fuel cells. J Power Sources. 2015;287:43-49.

11. Liu JD, Liu LF, Gao B. The tubular MFC with carbon tube air-cathode for power generation and N,N-dimethylacetamide treatment. Environ Technol. $2016 ; 37: 762-767$

12. Yamashita T, Ishida M, Ogino A, Yokoyama H. Evaluation of organic matter removal and electricity generation by using integrated microbial fuel cells for wastewater treatment. Environ Technol. 2016;37(2):228-236.

13. Lorenzo MD, Scott K, Curtis TP, Head IM. Effect of increasing anode surface area on the performance of a single chamber microbial fuel cell. Chem Eng J. $2010 ; 156: 40-48$.

14. Kumar GG, Sarathi VG, Nahm KS. Recent advances and challenges in the anode architecture and their modifications for the applications of microbial fuel cells. Biosens Bioelectron. 2013;43:461-475. 
15. Sivasankaran A, Sangeetha D, Ahn YH. Nanocomposite membranes based on sulfonated polystyrene ethylene butylene polystyrene (SSEBS) and sulfonated $\mathrm{SiO}_{2}$ for microbial fuel cell application. Chem Eng J.2016;289:442-451.

16. Tang JH, Yuan Y, Liu T, Zhou SG. High-capacity carbon-coated titanium dioxide core-shell nanoparticles modified three dimensional anodes for improved energy output in microbial fuel cells. J Power Sources. 2015;247:170-176.

17. Yin T, Lin ZY, Su L, Yuan CW, Fu DG. Preparation of vertically oriented $\mathrm{TiO}_{2}$ nanosheets modified carbon paper electrode and its enhancement to the performance of MFCs. ACS Appl Mater Interfaces. 2015;7:400-408.

18. Wang L, Su L, Chen HH, Yin T, Lin ZY, Lin XX, Yuan CW, Fu DG. Carbon paper electrode modified by goethite nanowhiskers promotes bacterial extracellular electron transfer. Mater Lett. 2015;141:311-314.

19. Hidalgo D, Tommasi T, Bocchini S, Chiolerio A, Chiodoni A, Mazzarino I, Ruggeri B. Surface modification of commercial carbon felt used as anode for microbial fuel cells. Energy. 2016;99:193-201.

20. Liu H, Ramnarayanan R, Logan BE. Production of electricity during wastewater treatment using a single chamber microbial fuel cell. Environ Sci Technol. 2004;38:2281-2285.

21. Zhu NW, Chen X, Zhang T, Wu PX, Li P, Wu JH. Improved performance of membrane free single-chamber air-cathode microbial fuel cells with nitric acid and ethylenediamine surface modified activated carbon fiber felt anodes. Bioresour Technol. 2011;102:422-426. 
407

408

409

410

411

412

413

414

415

416

417

418

419

420

421

422

423

424

425

426

427

428

22. Cai J, Zheng P. Simultaneous anaerobic sulfide and nitrate removal in microbial fuel cell. Bioresour Technol. 2013;128:760-764.

23. Zhao F, Rahunen N, Varcoe JR, Avignone-Rossa C, Thumser AE, SladeRCT. Factors affecting the performance of microbial fuel cells for sulfur pollutants removal. Biosens Bioelectron. 2009;24:1931-1936.

24. Fatemi S, Ghoreyshi AA, Rahimnejad M, Darzi GN, Pant D. Sulfide as an alternative electron donor to glucose for power generation in mediator-less microbial fuel cell. J Environ Sci Health Part A. 2017;52:1150-1157.

25. Cai J, Zheng P, Qaisar M, Xing YJ. Effect of operating modes on simultaneous anaerobic sulfide and nitrate removal in microbial fuel cell. J Ind Microbiol Biotechnol. 2014;41:795-802.

26. Rakoczy J, Feisthauer S, Wasmund K, Bombach P, Neu TR, Vogt C, Richnow HH. Benzene and sulfide removal from groundwater treated in a microbial fuel cell. Biotechnol Bioeng. 2013;110:3104-3113.

27. Zhang L, Mao Y, Ma J, Li D, Shi H, Liu Y, Cai L. Effect of the chemical oxidation demand to sulfide ratio on sulfide oxidation in microbial fuel cells treating sulfide-rich wastewater. Environ Technol. 2013;34:269-274.

28. Cai J, Zheng P, Qaisar M, Sun P. Effect of electrode types on simultaneous anaerobic sulfide and nitrate removal in microbial fuel cell. Sep Purif Technol. $2014 ; 134: 20-25$.

29. Zhang BG, Zhou SG, Zhao HZ, Shi CH, Kong LC, Sun JJ, Ni JR. Factors affecting the performance of microbial fuel cells for sulfide and vanadium (V) 
treatment. Bioproc Biosyst Eng. 2010;33:187-194.

30. Liu HP, Zhang BG, Liu Y, Wang ZJ, Hao LT. Continuous bioelectricity generation with simultaneous sulfide and organics removals in an anaerobic baffled stacking microbial fuel cell. Int J Hydrogen Energy. 2015;40:8128-8136.

31. Cline JD. Spectrophotometric determination of hydrogen sulphide in natural waters. Limnol Oceanogr. 1969;14:454-458.

32. Wei JC, Liang P, Cao XX, Huang X. A new insight into potential regulation on growth and power generation of Geobacter sulfurreducens in microbial fuel cells based on energy viewpoint. Environ Sci Technol. 2010;44:3187-3191.

33. Xiao B, Han Y, Liu X, Liu J. Relationship of methane and electricity production in two-chamber microbial fuel cell using sewage sludge as substrate. Int J Hydrogen Energy. 2014;39:16419-16425.

34. Logan BE, Hamelers B, Rozendal R, Schröder U, Keller J, Freguia S, Aelterman P, Verstraete W, Rabaey K. Microbial fuel cells: methodology and technology. Environ Sci Technol. 2006;40:5181-5192.

35. Hao LT, Zhang BG, Cheng M, Feng CP. Effects of various organic carbon sources on simultaneous $\mathrm{V}(\mathrm{V})$ reduction and bioelectricity generation in single chamber microbial fuel cells. Bioresour Technol. 2016;201:105-110.

36. Qiao Y, Bao SJ, Li CM, Cui X Q, Lu ZS, Guo J. Nanostructured polyaniline/titanium dioxide composite anode for microbial fuel cells. ACS Nano. 2008;2:113-119.

37. Lu AH, Li Y, Jin S, Wang X, Wu XL, Zeng CP, Li Y, Ding HR, Hao RX, Lv M, 
451

452

453

454

455

456

457

458

459

460

461

462

463

464

465

466

467

468

469

470

471

472

Wang CQ, Tang YQ, Dong HL. Growth of non-phototrophic microorganisms using solar energy through mineral photocatalysis. Nat Commun. 2012;3:768.

38. Min B, Cheng S, Logan BE. Electricity generation using membrane and salt bridge microbial fuel cells. Water Res. 2005;39:1675-1686.

39. Bond D R, Lovley D R. Electricity production by Geobacter sulfurreducensattached to electrodes. Appl Environ Microbiol. $2003 ; 69: 1548-1555$.

40. Ieropoulos I,Greenman J, Melhuish C, Hart J. Energy accumulation and improved performance in microbial fuel cells. J Power Sources. 2005;145:253-256.

41. Aelterman P, Freguia S, Keller J, Verstraete W, Rabaey K. The anode potential regulates bacterial activity in microbial fuel cells. Appl Microbiol Biotechnol. 2008;78:409-418.

42. Zhou MH, Chi M, Wang H, Jin T. Anode modification by electrochemical oxidation: a new practical method to improve the performance of microbial fuel cells. Biochem Eng J. 2012;60:151-155.

43. Cai J, Zheng P, Xing Y, Qaisar M. Effect of electricity on microbial community of microbial fuel cell simultaneously treating sulfide and nitrate. J Power Sources. 2015;281:27-33.

44. Raschitora A, Soreanub G, Fernandez-Marchantea CM, Lobatoa J, Cañizaresa P, Cretescub I, Rodrigoa MA. Bioelectro-Claus processes using MFC technology: Influence of co-substrate. Bioresour Technol. 2015;189:94-98.

45. Zhang J, Zhang BG, Tian CX, Ye ZF, Liu Y, Lei Z, Feng CP. Simultaneous sulfide 
removal and electricity generation with corn stover biomass as co-substrate in 
$495 \quad$ cell. Anaerobe. 2001;7:297-306.

496 52. Srinivas TNR, Kumar PA, Sasikala C, Ramana CV, Imhoff JF. Rhodobacter

497 vinaykumarii sp. nov., a marine phototrophic alphaproteobacterium from tidal

498 waters, and emended description of the genus Rhodobacter. Int J Syst Evol Micr.

499 2007;57:1984-1987.

500 
2

3

4

5

6

7

8

9

10

11

501 Figure Captions.

502 Fig. 1. SEM images and EDX spectral intensities. (a) with $\mathrm{TiO}_{2}$ nanosheets, (b) with

$503 \mathrm{Fe}_{2} \mathrm{O}_{3}$ nanosheets, (c) bare carbon-fiber-felt, (d) corresponding EDX spectral

504 intensities.

505 Fig. 2. (a) Polarization curves and power outputs as well as (b) anode potentials of

506 MFCs with three kinds of anodes.

507 Fig. 3. (a) CV and (b) Nyquist plot of EIS data for the anodes of three MFCs.

508 Fig. 4. Changes of sulfide and TOC during $48 \mathrm{~h}$ operation as well as the generated

509 sulfate in the anode chambers of three MFCs. The black legend referred to left vertical

510 axis while the red legend referred to the right vertical axis. 
512 Table 1. Alpha-diversity of three MFCs employed in this study.

\begin{tabular}{cccccc}
\hline Type & Ace & Chao & Shannon & Simpson & Coverage \\
\hline${\mathrm{MFC}-\mathrm{TiO}_{2}}$ & 768 & 760 & 4.33 & 0.031 & 0.996 \\
$\mathrm{MFC}-\mathrm{Fe}_{2} \mathrm{O}_{3}$ & 505 & 493 & 2.69 & 0.192 & 0.996 \\
$\mathrm{MFC}-\mathrm{CF}$ & 394 & 375 & 2.45 & 0.240 & 0.995 \\
\hline
\end{tabular}


Table 2. Percentages of sequences identified to different phylogenies in the MFCs with three different anodes.

\begin{tabular}{|c|c|c|c|c|c|c|c|c|c|c|c|}
\hline Phylum & Class & Genus & $\begin{array}{c}\text { MFC- } \\
\mathrm{TiO}_{2} \\
(\%)\end{array}$ & $\begin{array}{c}\text { MFC- } \\
\mathrm{Fe}_{2} \mathrm{O}_{3} \\
(\%)\end{array}$ & $\begin{array}{c}\text { MFC } \\
-C F \\
(\%)\end{array}$ & Phylum & Class & Genus & $\begin{array}{c}\text { MF } \\
\text { C-Ti } \\
O_{2} \\
(\%)\end{array}$ & $\begin{array}{c}\text { MFC- } \\
\mathrm{Fe}_{2} \mathrm{O}_{3} \\
(\%)\end{array}$ & $\begin{array}{c}\text { MFC } \\
\text {-CF } \\
(\%)\end{array}$ \\
\hline \multirow{4}{*}{ Acidobacteria } & Acidobacteria & norank & 0.12 & 0.17 & 0.32 & Nitrospirae & Nitrospira & norank & 0.21 & 0.01 & 0.28 \\
\hline & Holophagae & norank & 5.30 & 5.55 & 0.00 & \multirow{3}{*}{ Planctomycetes } & \multirow{3}{*}{ Planctomycetacia } & Gemmata & 0.73 & 0.68 & 0.00 \\
\hline & Actinobacteria & uncultured & 0.40 & 0.15 & 0.46 & & & Pirellula & 0.96 & 0.42 & 1.31 \\
\hline & Thermoleophilia & Gaiella & 0.30 & 0.17 & 0.44 & & & Planctomyces & 1.81 & 1.75 & 0.00 \\
\hline \multirow[t]{2}{*}{ Armatimonadetes } & norank & norank & 0.07 & 0.08 & 0.07 & & & uncultured & 0.47 & 0.20 & 1.03 \\
\hline & Bacteroidia & & 4.41 & 1.03 & 0.71 & & & norank & 0.18 & 0.14 & 0.30 \\
\hline \multirow{3}{*}{ Bacteroidetes } & Sphingobacteriia & norank & 0.42 & 0.03 & 0.00 & & \multirow{3}{*}{ Alphaproteobacteria } & Rhodobacter & 0.04 & 0.02 & 14.8 \\
\hline & Sphingobacteriia & & 0.00 & 0.22 & 0.48 & & & Delftia & 0.78 & 1.47 & 1.41 \\
\hline & vadinHA17 & norank & 0.11 & 0.17 & 0.03 & & & Thiobacillus & 1.21 & 0.01 & 0.00 \\
\hline \multirow[t]{2}{*}{$\begin{array}{c}\text { Candidate division } \\
\text { BRC1 }\end{array}$} & norank & norank & 1.94 & 0.46 & 0.25 & Proteobacteria & Deltaproteobacteria & Desulfovibrio & 12.97 & 6.86 & 4.30 \\
\hline & Anaerolineae & Leptolinea & 0.88 & 0.12 & 0.00 & & \multirow[b]{2}{*}{ Gammaproteobacteria } & norank & 21.94 & 47.44 & 28.6 \\
\hline Chloroflexi & Caldilineae & uncultured & 0.98 & 0.43 & 0.42 & & & $\begin{array}{c}\text { Pseudoxanth } \\
\text { omonas }\end{array}$ & 0.90 & 0.00 & 4.63 \\
\hline \multirow{3}{*}{ Firmicutes } & \multirow{2}{*}{ Clostridia } & Anaerofustis & 0.01 & 0.00 & 0.17 & Spirochaetae & Spirochaetes & Spirochaeta & 0.10 & 0.05 & 0.11 \\
\hline & & Incertae_Sedis & 0.94 & 0.05 & 37.88 & Synergistetes & Synergistia & uncultured & 3.75 & 0.09 & 0.02 \\
\hline & Negativicutes & norank & 37.26 & 31.73 & 0.03 & Others & & & 0.81 & 0.50 & 1.95 \\
\hline
\end{tabular}



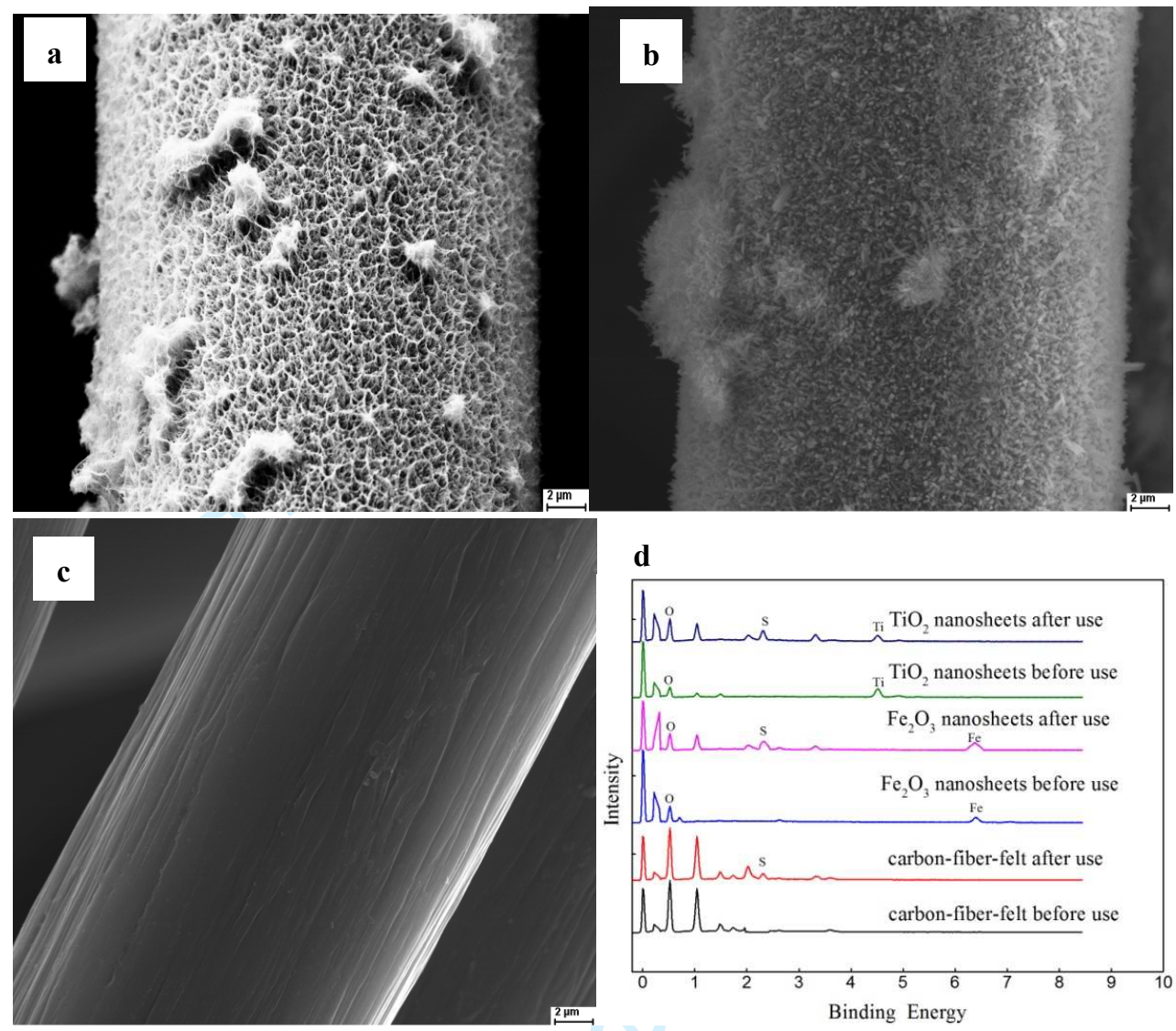

Figure 1 

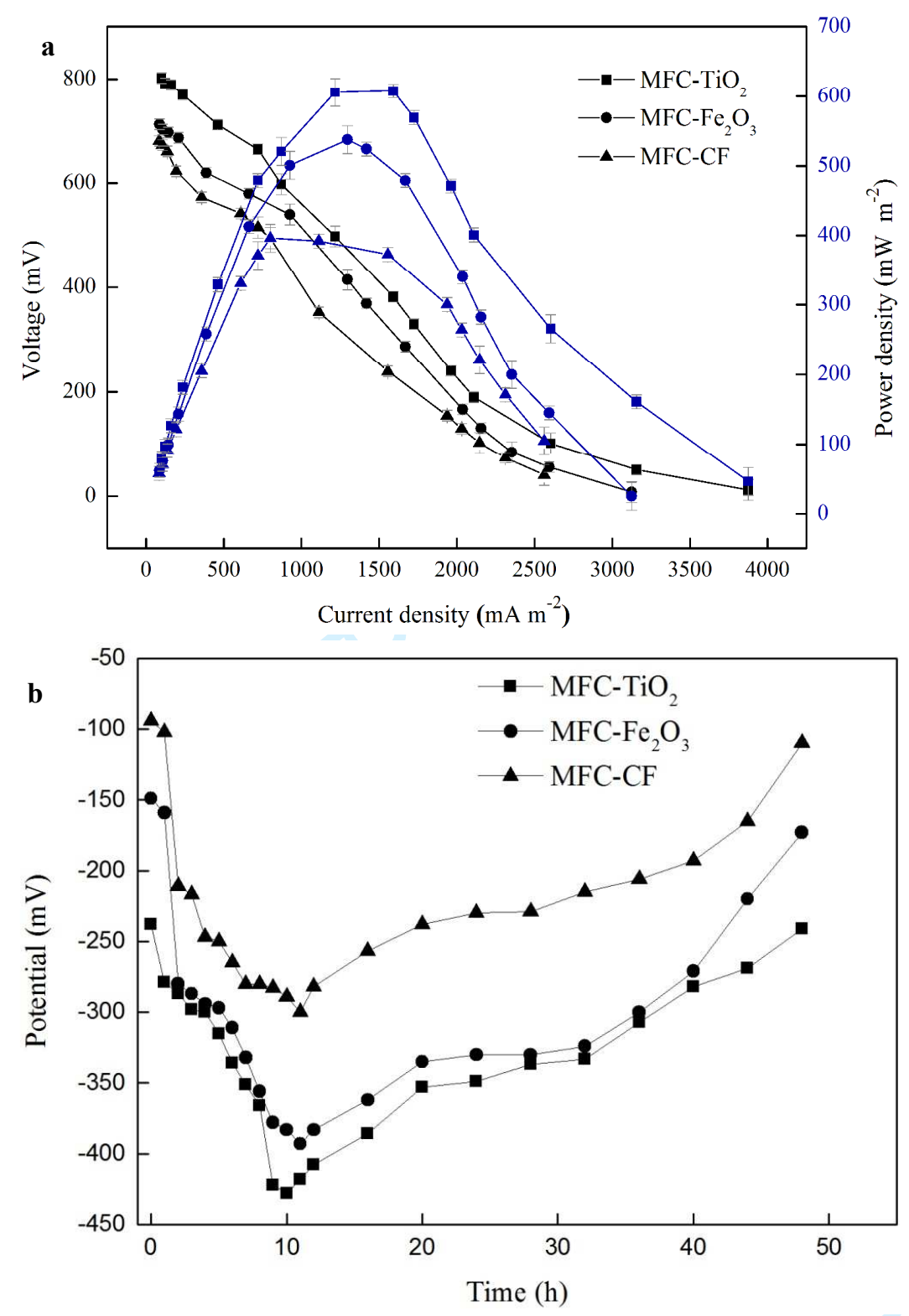

Figure 2 

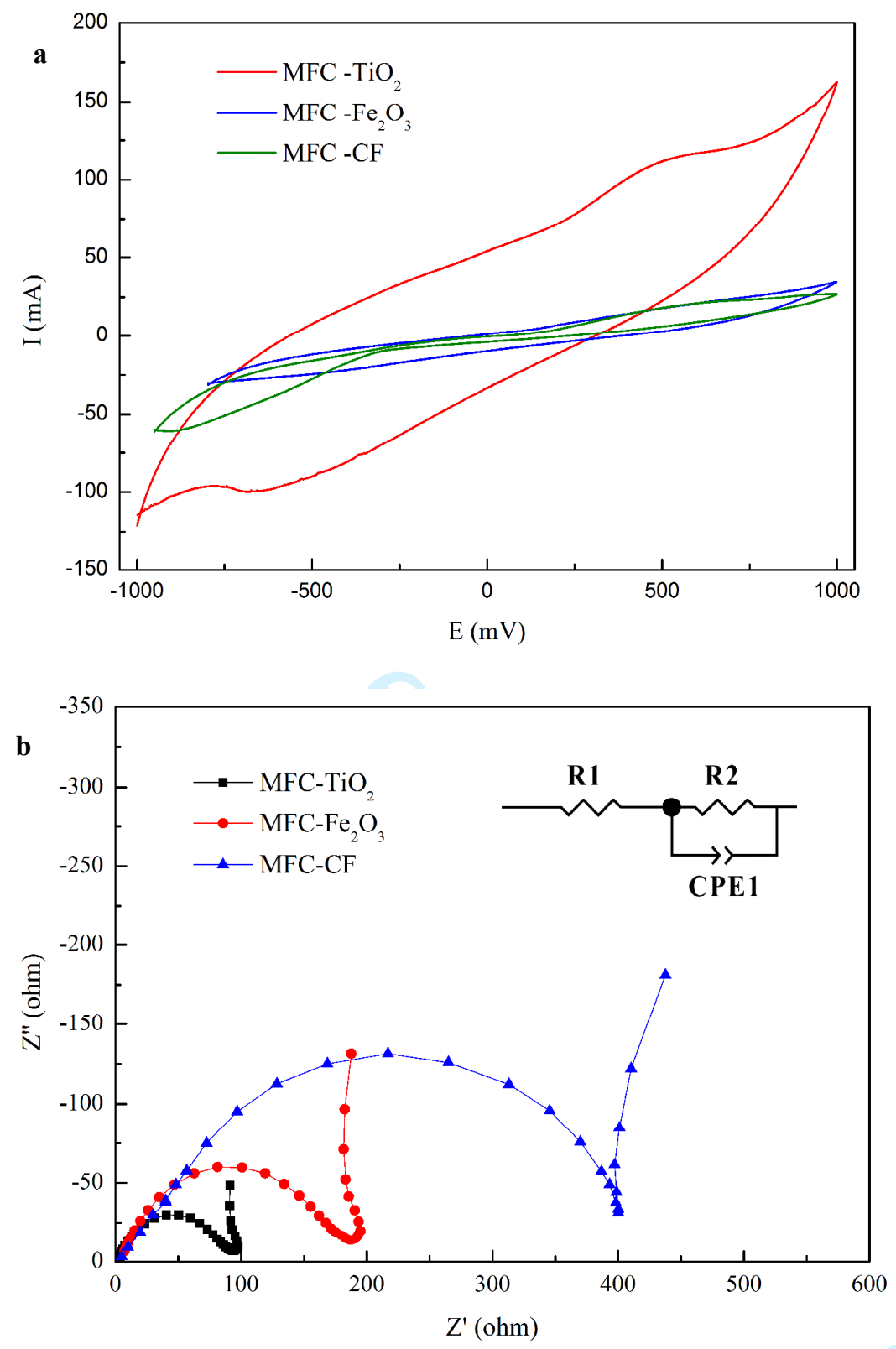

Figure 3 


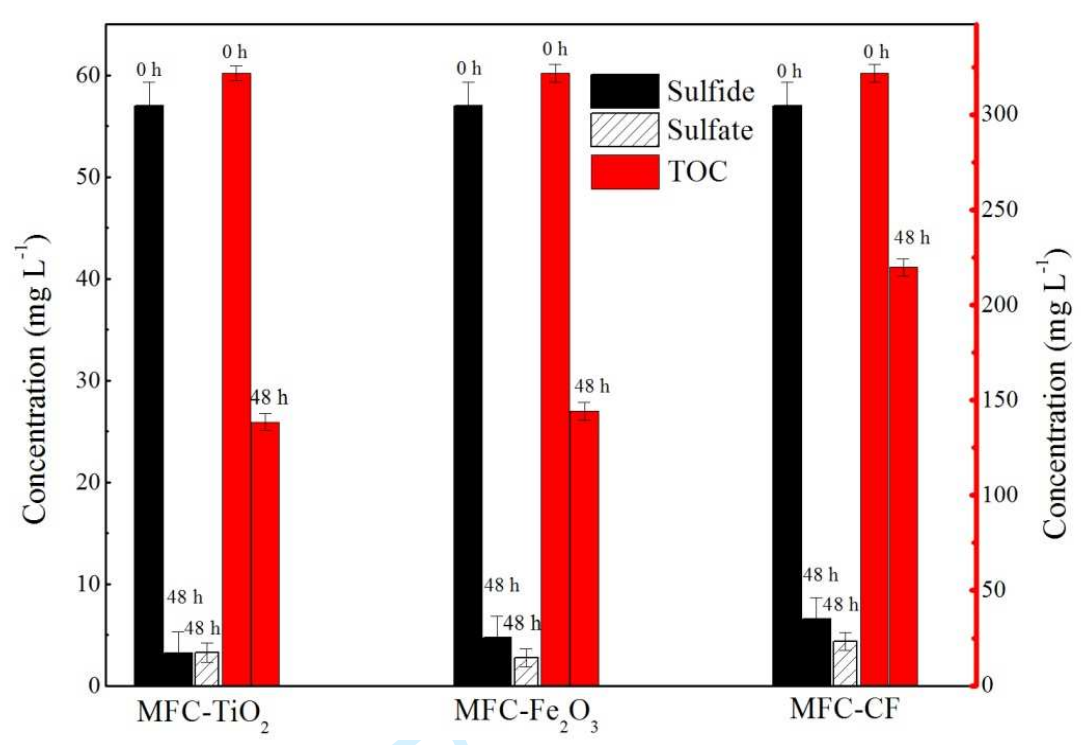

Figure 4 


\title{
Supporting Information
}

\section{Enhanced sulfide removal and bioelectricity generation in microbial fuel cells with anodes modified by vertically oriented nanosheets}

\author{
Meng Yang ${ }^{\text {a,\#, Yuezhi Zhong }}{ }^{\text {a,\#}, \text { Baogang Zhang }}{ }^{\text {a, }}$, Jiaxin Shi ${ }^{\mathrm{a}}$, Xueyang Huang ${ }^{\mathrm{a}}$, Yi \\ Xing $^{\text {b, }}$, Lin $\mathrm{Su}^{\mathrm{c}}$, Huipeng Liu ${ }^{\mathrm{a}}$, Alistair G.L. Borthwick ${ }^{\mathrm{d}}$ \\ ${ }^{a}$ School of Water Resources and Environment, MOE Key Laboratory of Groundwater \\ Circulation and Environmental Evolution, China University of Geosciences (Beijing), \\ Beijing 100083, P. R. China \\ ${ }^{b}$ School of Energy and Environmental Engineering, University of Sciences and \\ Technology Beijing, Beijing Key Laboratory of Resource-oriented Treatment of \\ Industrial Pollutants, Beijing 100083, P. R. China \\ ${ }^{c}$ State Key Laboratory of Bioelectronics, Southeast University, Nanjing 210096, P. R. \\ China \\ ${ }^{d}$ School of Engineering, The University of Edinburgh, The King's Buildings, \\ Edinburgh EH9 3JL, UK
}

\footnotetext{
${ }^{\#}$ These authors contributed equally to this work.

${ }^{*}$ Corresponding author. Tel.: +86108232 2281; fax: +861082321081.

E-mail: zbgcugb@gmail.com, baogangzhang@cugb.edu.cn (B. Zhang); xing_bkd@163.com (Y. Xing).
}

$\mathrm{S} 1$ 

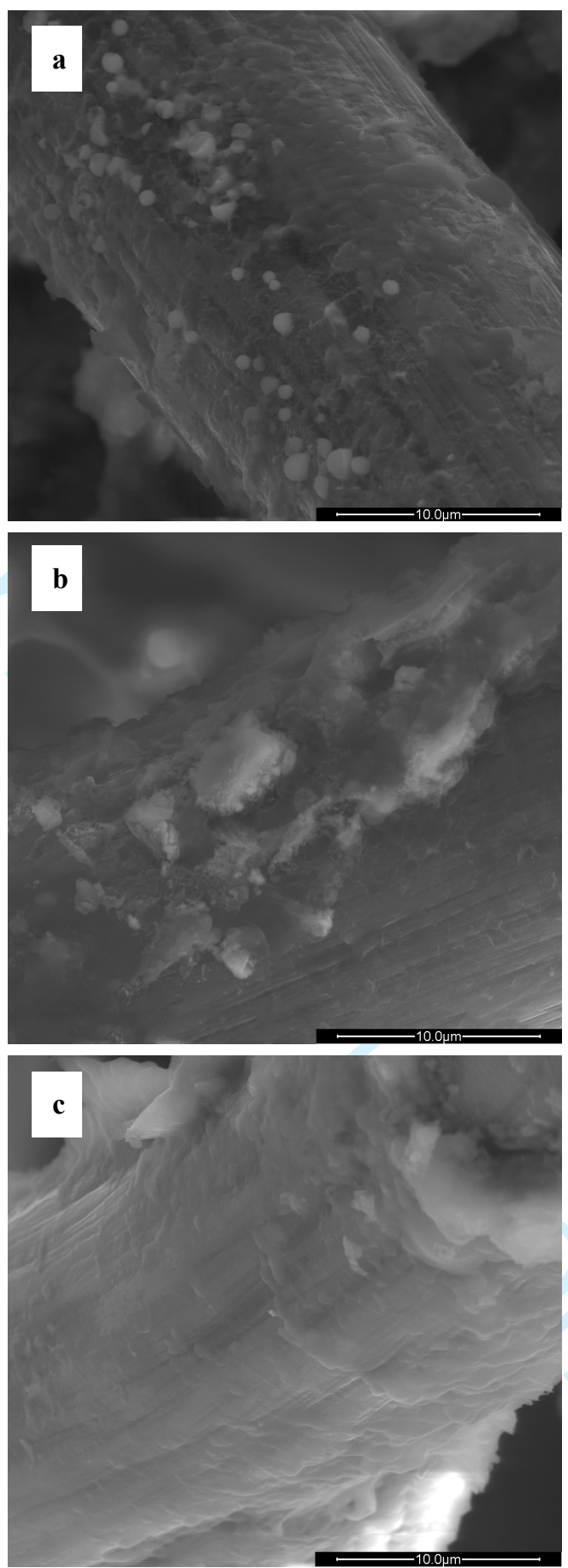

Figure S1. SEM images of anodes in the three MFCs after the whole experiment. (a)

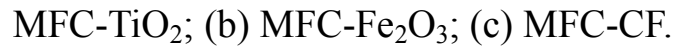

